\title{
Impact of ISO 9001 Certification on the Projects' Success of Large-Scale (AAA) Construction Firms in the Philippines
}

Article history:

Received, October $10^{\text {th }}, 2016$; Accepted in revised form, October $20^{\text {th }}, 2016$;

Approved, October 22 ${ }^{\text {nd }}, 2016$; Available online, November $2^{\text {nd }}, 2016$.

\section{Keywords:}

Construction Quality;

ISO 9001 Certification;

Customer's satisfaction;

Construction Project

Success;Quality Management

System;

\begin{abstract}
The general purpose of this study is to investigate the effects of ISO 9001 certification on project success, and its main criteria into large-scale construction companies in Metro Manila, Philippines. For this aim, the research was conducted an in-depth literature review for identifying the main variables first. Subsequently, a survey questionnaire was designed, and distributed randomly among 67 managers working in ISO 9001:2008certified projects of large-scale construction firms. Then the descriptive and inferential statistics analysis employed, in order to find the results and conclusions. Finally, the findings revealed that ISO 9001 certification can significatly affect the construction project success and its main criteria, except time lenght of projects in Metro Manila, Philippines.
\end{abstract}

2395-7492@ Copyright 2016 The Author. Published by International Journal of College and University. This is an open access article under the CC-BY-SA license (https://creativecommons.org/licenses/by/4.0/) All rights reserved.

\section{Author correspondence:}

First Author,

Doctorate Program, Department of Civil Engineering,

De La Salle University, Manila, Philippines

Email address : behnam_neyestan@dlsu.edu.ph

\section{Introduction}

Construction industry has an important role to reduce unemployment rate, stimulate economic growth, and likewise generate residential, non-residential and infrastructure. Dramatically, over the past three decades, numerous government and business organizations reported that construction industry in many parts of the world suffers from several problems, especially for low quality (Ali and Rahmat, 2010). "Great amount of time, money and resources, both human and material, are wasted each year in the construction industry for inefficiency, or lack of quality management procedure" (Polat et al., 2012, p. 1115). With the turn of the new millennium, global competition has increased. The increasing effects of globalization and competitive pressure have generated an important question in construction industry, how can the construction companies complete the projects successfully in a global market?

Kerzner (2010) pointed out successful project can be defined as having achieved the project objectives, such as the accomplishment of project on time, within cost, and accepted quality, and promoting customer's satisfaction. Quality is the most significant factor in the success of projects, which can affect on cost and time length of projects' completion, in order to satisfy customers in construction

\footnotetext{
${ }^{a}$ Doctorate Program, Department of Civil Engineering, De La Salle University, Manila, Philippines
} 
firms (Ali and Rahmat, 2010). Therefore, quality management should provide an appropriate environment by suitable tools, techniques, and procedures for implementing construction project successfully (Mane and Patil, 2015). There are different methodologies, approaches and tools that the construction firms can use to manage and maintain quality at project level. The most important technique in this field is ISO 9001 standard, and it is important for both practitioners and academics. The first edition of ISO 9001 as a quality assurance standard was officially introduced in 1987 by the International Organization for Standardization (ISO), in order to improve quality and customers' satisfaction within manufacturing sectors first. Later ISO 9001 standard was accepted by the construction community as the quality policy all over the world in the end of 1990s (Lee et al., 2011). From the last two decade ISO 9001 standard has been widely accepted in construction industry at the international level. "Many benefits are gathered throughout the globe by its effective implementation" (Khattak and Arshad, 2015, P. 203), especially since 2000 , when it became as a quality management standard.

Interestingly, numerous case studies revealed that ISO 9001 standard can improve project quality performance, avoid costly errors and delay, and satisfy customers in construction projects (Farooqui and Ahmed, 2009). While some argued that the level of the effects of ISO 9001-certified contractors on the most important elements of construction projects are still ambiguous (Ali and Rahmat, 2010). Also, literature survey indicated a few studies conducted concerning this topic by scholars in manufacturing and service sectors only, whereas no study was sufficiently found related to this problem in construction area. Consequently, it is vital to identify the role of ISO 9001 standard on the success of construction projects. Thus, the main objective of this research was to evaluate the effects of ISO 9001:2008 certification on project success, and its main criteria, such as construction quality, time length of project, cost of project, and customer's satisfaction within projects of large-scale construction companies in Metro Manila, Philippines.

\section{Literature Review}

Overview of ISO 9001 Standard

ISO 9001 is a system based on the Plan, Do, Check, Act (PDCA) cycle, through "documentation", "implementation", "audit", and review for improving quality performance in the organizations (Oakland, 2003). ISO 9001 standard is one of the most successful quality management tools. This standard was first introduced by the International Organization for Standardization (ISO) on 15, March 1987, by technical committee of ISO/ TC-176 (khattak, and Arshad, 2015). ISO 9001 is a set of the requirements for a quality management system (QMS), this standard is a generic standard for all organizations, regardless of their size and field of activity that aims satisfying customers' needs. It is widely adopted by different sectors in 188 countries, the total numbers of ISO 9001-certified firms was about 1,138,155 certificates by 2014 (ISO, 2014). ISO has revised ISO 9001 certification four times in 1994, 2000, 2008, and 2015. The changes of the market, customer's needs, and the correction of the standard are the main issues to revise ISO 9001 standard (Shafiq et al., 2014). The first two editions of ISO 9001 were quality assurance standard, but this standard became as a quality management standard, since when ISO published 2000 revision. Interestingly, ISO 9001:2000 adopted process approach and PDCA cycle, which caused that the fims improve quality performance continuously.

In 2008, ISO 9001 was published in with minimum changes made from the 2000 revision (The same structure and clauses), but greater emphasis on customer focus and satisfaction. ISO 9001:2008 is to clarify existing requirements and to improve consistency of approach with other management standards (ISO, 2010). ISO 9001:2008 has eight clauses as its requirements, the first three clauses do not provide any requirements for a QMS. They provide background information regarding QMS, and last five clauses constitute the main body of ISO 9001 standard to comply into the organization (ISO, 2008). These clauses demonstrate the requirements of the ISO 9001:2008 as a framework for implementing QMS that based on PDCA methodology. Meanwhile, QMS should interact with production processes through the documentation in the organization (Oakland, 2003). However, the main aims of the process approach in QMS are to increase an organization's effectiveness and efficiency, in order to satisfy customers by "identifying" and "eliminating" the root causes of the production problems (e.g. errors, defects, delay, etc.) (ISO, 2008).

\section{Project Success, and its Main Criteria in Construction Industry}

As in any other business, the intention of each construction project is to achieve success, and the project success depends on the expectations and requirements of a project as its goals (Proust, 2011). Therefore, it is important to identify the construction project success criteria as the main objectives of projects. According to Shahu et al. (2012), numerous authors investigated the subject on project success but the concept of project success is still vaguely defined. it seems that the identification of project 
success is complicated. However, there still remains ambiguity in the question, what exactly project success is?

Although the authors and experts have not determined similar factors as project success criteria, but all of them are agreed that iron triangle includes the most important criteria as main objectives for the success of construction projects (Golob et al., 2013; Varajão et al., 2014). For a successful project management, cost and time of the project should be minimized while the project quality is maximized as main elements of iron triangle (Hajiagha et al., 2015; Shahu et al., 2012). Accordingly, these three factors are "predominant" in the management of usual construction projects (Proust, 2011). Also, customer's satisfaction is a fundamental issue for construction projects (Ali and Rahmat, 2010), and it has a key role to assess the construction project success as well as iron triangle does. Some authors like Kerzner (2010) defined the project success as the one that assesses both primary and secondary factors. Primary factors (iron triangle criteria) include meeting deadlines, budget limit, and the level of expected quality in construction (Golob et al., 2013; Varajão et al., 2014), while secondary factors of project success are involved the issues related customer's satisfaction as external factors of project success (Proust, 2011). Consequently, project success can be defined as internal factors that are time, cost, and quality, and likewise, external factors, which are related to customer's satisfaction.

\section{Impact of ISO 9001 on Construction Project Success, and its Criteria}

As mentioned previously, the main aspects of successful construction projects are to deliver projects with high quality and on time, complete project with minimum expenses, and satisfy customers, as the construction project success criteria. Doubtlessly, ISO 9001 provides a proper "environment" that assists construction projects in achieving these goals (Mane and Patil, 2015). This quality management technique can maintain and improve quality performance continuously at construction project level (Farooqui and Ahmed, 2009), and likewise being as "a key tool in consistently and reliably managing the goal of client's satisfaction" (Mane and Patil, 2015, p. 126). Similarly, Oakland (2003) stated ISO 9001 can establish a system for ensuring that all the products/services enable to meet the requirements and needs of customers.

Based on the literature review, numerous case studies were found, which demonstrated the ability of ISO 9001 in improving construction quality performance, avoiding costly errors and delay, and satisfying customers into construction projects (Farooqui and Ahmed, 2009). For example, the empirical study of khattak, and Arshad (2015) proved that the errors from the start, delay, and quality cost of ISO 9001certified construction projects are significantly less than the Pakistani construction projects without ISO 9001 certification in contrast, because ISO 9001-certified construction projects emphasize and practice more on "customer focus", "process management" and "continuous improvement" (Shafiq et al., 2014). Interestingly, the findings of Ali, and Rahmat (2010) from Malaysian construction companies revealed that functionality (conformance to specifications), and customer's satisfaction were scored by the respondents as most effects of ISO 9001 certification on construction projects. Also, Mane and Patil (2015) discovered that the most advantage of ISO 9001 certification was significantly customer's satisfaction into Indian construction projects.

\section{Research Method}

\subsection{Research Hypotheses and Conceptual Framework}

Based on previous discussions the following hypotheses are built to investigate the impact of the ISO 9001 certification on project success, and likewise its criteria in large-scale large-scale construction firms:

H1: ISO 9001 certification has significantly a positive influence on construction project success.

H2: ISO 9001 certification positively affects construction quality performance.

H3: ISO 9001 certification can significantly deliver the construction project on time.

H4: ISO 9001 certification significantly minimizes the expenses of project completion.

H5: ISO 9001 certification enhances the satisfaction of customers in construction projects.

According to theses hypotheses, the independent variable is ISO 9001 while the dependent variables are the project success and its main criteria, such as quality performance, cost of project, time length of project completion, and customer's satisfaction. The variables and their relationship are depicted in Figure 
1.

\section{Dependent Variables}

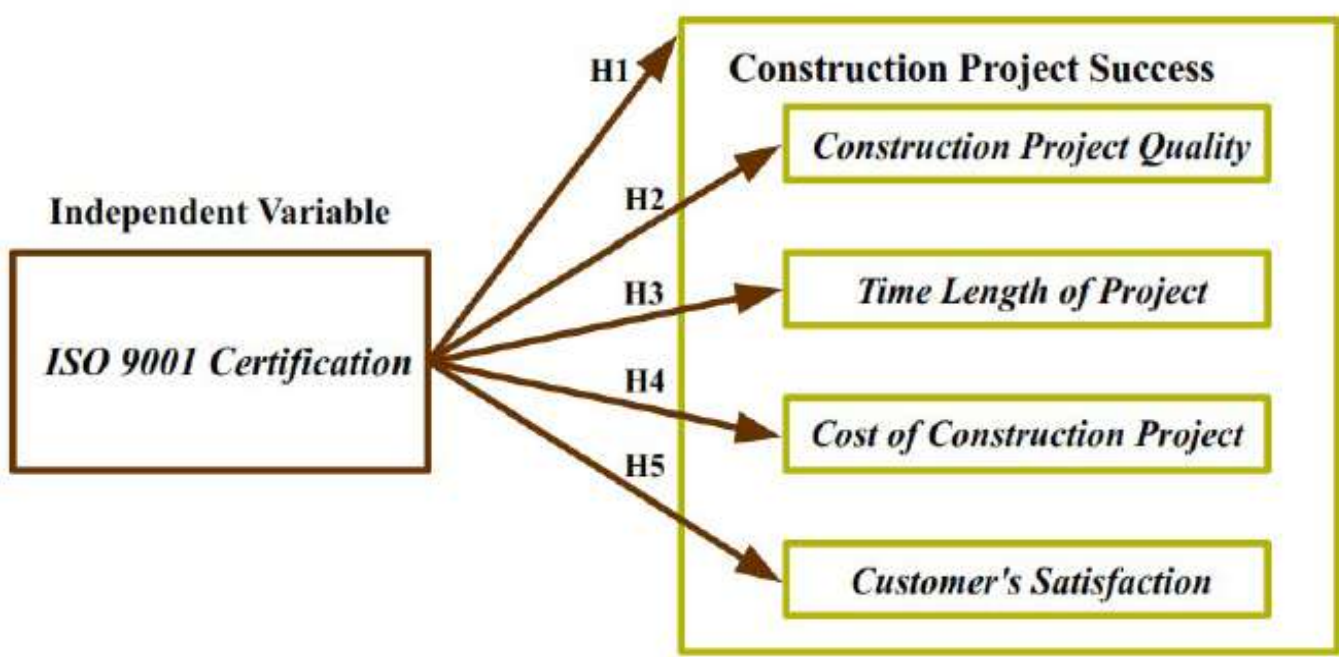

Figure 1: Conceptual framework

\subsection{Methodology}

Research Design

In this research, as a quantitative and likewise the cross-sectional study, survey strategy was adopted for collecting data at a particular time (short-term). The collected data was analyzed by statistical methods to identify the effects of ISO 9001 standard on project success, and its main elements within large-scale (AAA) construction companies in Metro Manila, Philippines.

\section{Data Collection}

Literature review was carried out for understanding the topic, and identifying the problems. Subsequently, a survey questionnaire was designed based on literature review, in order to collect primary data. Using the questionnaire can let the researcher collect data faster and cheaper than any other instrument. In this study, the survey questionnaire was finalized of 48 items, which divided in three main parts. Part I is related to demographic questions. Part II is focused on the requirements, or clauses of ISO 9001:2008. Part III has four sections, and each section is concerned to the impact of ISO 9001:2008 certification on each criterion of the project success, such as time, cost, quality, and client's satisfaction. According to Cohen et al. (2007) and Saunders et al., (2009), closed questions with Likert scales are proper and widely used in measuring the respondent's opinion. Therefore, the questionnaire was designed based on closed ended questions that let the participants give their responses appropriately corresponding their personal experiences and opinions, to the different variables by a "five-point Likert-style scale" (e.g. a scale from 1 to 5 , strongly disagreement= 1 , to Strongly agreement= 5). Meanwhile, the reliability and validity of items of research instrument tested carefully before descriptive and inferential analysis.

\section{Sampling Technique and Sample Size}

For sampling, the simple random sampling method was used. Thus, the questionnaires randomly distributed to the individuals working from different construction companies that have been ISO 9001:2008-certified. Furthermore, the sample of this study was belonged to the infrastructure and building projects of AAA (Large-scale) construction firms in Metro Manila, Philippines. These AAA construction firms extracted and selected from the list of Philippine Contractors Accreditation Board (PCAB, 2015). Likewise, the respondents of this research were managers in different management levels, areas, and specialists from projects of top construction firms. For enhancing the number of the participants, the delivery and collection of the questionnaires carried out by researcher, as recommended by Saunders et al. (2009), in this method, the response rate can be achievable as high as 98 per cent. However, a total of eighty questionnaires that sent to the AAA construction companies, just $84 \%$ of them were duly completed. Accordingly, the response rate of $84 \%$ achieved valid out of the 80 questionnaires, or the 67 usable questionnaires that used in the statistical analysis of this research. 
Data Analysis

The results of the questionnaires being analyzed by using SPSS (Statistical Package for the Social Sciences) Version 17 software in this study. This statistical software (SPSS) has been employed for measuring the reliability of the instrument first. Then several techniques of the descriptive and inferential statistics used to analyze the impact of ISO 9001:2008 on construction project success, and its main criteria. The mean value, standard deviation, skewness, and kurtosis were used for descriptive statistics. In inferential statistics analysis, the hypotheses were estimated by simple regression analysis as an appropriate technique for this study, and all statistical tests calculated at the significance level of 0.05 and 1-tailed.

\section{Specification of Models}

This study has been constructed five Models to test the contribution of ISO 9001 (independent variable) in predicting project success as whole, and its main factors into large-scale construction projects. Therefore, the effects of independent variable on dependent variables were tested using the following regression equations:

$$
\begin{aligned}
& \text { Model 1 }=\beta 0+\beta 1 * X+\varepsilon \\
& \text { Model 2 }=\beta 0+\beta 2 * X+\varepsilon \\
& \text { Model } 3=\beta 0+\beta 3 * X+\varepsilon \\
& \text { Model } 4=\beta 0+\beta 4 * X+\varepsilon \\
& \text { Model } 5=\beta 0+\beta 5^{*} X+\varepsilon
\end{aligned}
$$

Where,

1] Model 1, Model 2...., Model 5 = Impact of ISO 9001 on project success, construction quality, time length of project, construction project cost, and customer's satisfaction respectively.

2] $\beta 0=$ Constant of proportionality;

3] $\mathrm{X}=\mathrm{ISO} 9001$ certification;

4] $\varepsilon=$ Error term

5] $\beta 1, \beta 2 . . \beta 5=$ Unstandardized regression coefficients of predictors viz, project success, construction quality, time length of project, construction project cost, and customer's satisfaction respectively.

\section{Results and Analysis}

\subsection{Reliability and validity of the research instrument}

This section is discussed concerning the validity and reliability of measurement questions. According to Saunders et al. (2009), a valid questionnaire can be able to collect data accurately. This study was inapplicable to evaluate the validity of measurement items by some statistical methods, such as the exploratory and confirmatory factor analysis, because the sample size of this study is very small (only 67 respondents). As stated by Hair et al. (2006) and Cohen et al. (2007), for calculating the questionnaire's validity by these methods, the sample size should be at least 100 respondents for exploratory factor analysis and the minimum of 150 participants is needed for confirmatory factor analysis. Therefore, the content validity was just used by the researcher for measuring the validity of the instrument in two steps.

In the first step, an appropriate sample of questions carefully built since the scale items of main constructs were extracted from a comprehensive literature review on ISO 9001:2008, and projects' success issues as well. Second, a pilot study conducted by sending the questionnaire to four academicians working in quality management field for reviewing and evaluating qualitatively/subjectively questions, with the aim of identifying that each measurement item is related to the content domain of the study, and likewise it is clear, understandable and easy to answer by the respondents. Finally, the items of the instrument revised based on the suggestions of theses experts, in order to assure the content validity of the instrument in this study.

Subsequently, a reliability test was conducted on the variables of the study after data collection. Reliability is related to "internal consistency" involves the correlation of the responses to each item with other items in the instrument. There are several techniques to evaluate internal consistency. For this study, Cronbach's alpha reliability coefficient was adopted as most popular used method for calculating the reliability of a scale item, or a set of the scale items (Saunders et al., 2009). The alpha coefficient of reliability, or the alpha $(\alpha)$ can be 0 to 1 , and the alpha is reliable if the reliability coefficient became 0.70 or more (Cohen et al., 2007). As indicated in Table 1, the alpha coefficient of independent variable (ISO 9001 certification) is 0.914 , which proved very high reliability of scales to measure the project success 
criteria. Furthermore, three questions of ISO 9001 items were unreliable, and they dropped from the list of independent variable items. While the overall values of Cronbach's alpha for dependent variable was 0.867, and confidently reliable. The values of Cronbach's alpha of each variable of the project success, such as quality, time, cost, and customer's satisfaction scales were respectively $0.796,0.848,0.861$, and 0.813 , and one item of the cost's questions was omitted as an unreliable item.

Table 2: Reliability Analysis

\begin{tabular}{|c|c|c|c|}
\hline Variable & No. of items before reliability & No. of items before reliability & $\begin{array}{c}\text { Cronbach's } \\
\text { Alpha }\end{array}$ \\
\hline ISO 9001 certification & 24 & 21 & .914 \\
\hline Quality & 5 & 5 & .796 \\
\hline Time & 5 & 5 & .848 \\
\hline Cost & 5 & 4 & .861 \\
\hline Customer's satisfaction & 5 & 5 & .813 \\
\hline
\end{tabular}

\subsection{Demographic data}

The findings of this study were obtained from 67 managers in different levels of management from projects of large-scale (AAA) construction companies in Metro Manila. The results showed that the majority of respondents were males about 61 individuals $(91 \%)$ while $9 \%$ of the respondents were females. Regarding work experience, 58 participating managers $(87 \%)$ had experiences in construction industry more than three years. In terms of age, the most of the participants were between 20 and 39 years old $(67 \%)$, and $32 \%$ of them belonged to other groups of age. Finally, the respondents were mostly B.Sc./B.Eng. and M.Sc./M.Eng. degree holders about $64 \%$ and $23 \%$ respectively, while the rest was about 9 respondents (13\%), who were belonged to other groups (Ph.D., Associate, and Diploma degree).

\subsection{Descriptive statistics analysis}

Table 2 is indicated the descriptive statistics, which includes mean score, standard deviation, skewness, and kurtosis for the variables of this study. The results of the descriptive statistics revealed that managers within construction projects perceived customer's satisfaction as most impact of ISO 9001:2008 on construction projects success criteria with the highest mean score that is 3.96, followed by quality and cost with the mean scores of 3.47 and 3.35 respectively, while time had the lowest mean of 3.21. Regarding ISO 9001 certification, the mean score was about 3.67 that indicates a high level of implementing ISO 9001 in the projects of large-scale construction firms in Metro Manila. The standard deviations (SD) are between 0.4820 and 0.8835 that proved the homogeneous data and less spread out or dispersed. Furthermore, the normality of the variables were measured using skewness and kurtosis levels to determine normality, the acceptable values of skewness and kurtosis is between -2.00 and +2.00 (Hair et al., 2006). As indicated in Table, the skewness and kurtosis levels are in satisfactory range. Thus, there are no outliers, and extreme values that might jeopardize and violate the validity of the analysis, and data was suitably distributed.

Table 2: Summary of the descriptive statistics of variables

\begin{tabular}{|c|c|c|c|c|}
\hline Criterion & M & SD & Skewness & Kurtosis \\
\hline ISO 9001 certification & 3.67 & .4820 & .113 & .481 \\
\hline Quality & 3.47 & .5304 & .293 & -.496 \\
\hline Time & 3.21 & .8835 & .927 & -.667 \\
\hline Cost & 3.35 & .6379 & -.358 & -.494 \\
\hline Customer's satisfaction & 3.96 & .8036 & .125 & -.782 \\
\hline
\end{tabular}




\subsection{Inferential statistics analysis}

As recommended by Cohen et al. (2007), simple linear regression analysis is the most appropriate technique to evaluate the impact of one independent variable only (ISO 9001) on dependent variables (project success variables). Therefore, simple linear regression was adopted in the study, this statistical method enables to determine the strength and direction taken by the linear correlation between independent and dependent variables whether the hypothesis is accept, or not. Importantly, there are some certain assumptions for using simple linear regression, which should be considered and operated fairly by researcher/s, in order to achieve reliable results. According to Hair et al. (2006), theses assumptions are such as linearity, normality, outliers, and multicollinearity.

Therefore, the normality, linearity, and collinearity tested before analyzing hypotheses. For this study, normality was assessed by normal probability plots (P-P Plots), for ISO 9001 certification as independent variable and construction project success elements as dependent variables. In regression analysis, the relationship between independent variable and dependent variables should be linear, In other words, the mean response scores at each value of the predictor variable should be fallen on a straight line. As depicted in Figure 2, Normal P-P Plots found that the residuals of model is normally disturbed, there are no outliers, and likewise the correlation between variables display a straight line.

Also, the the collinearity statistics should be employed through linear regression analysis to gauge the values of tolerance and VIF, with the aim of identifying that data is free from multi-collinearity problems. The analysis of the collinearity statistics indicated that there is no multi-collinearity problem in this study, because the tolerance value (0.3905) was greater than 0.10 and the value of VIF, or Variance Inflation Factor (2.633) was lower than 10, which means the model is credible, and it can be concluded that the findings of the regression analysis are acceptable (Hair et al., 2006). Finally, linear regression analysis cannot be applied to examine hypotheses with a small sample size. Interestingly, the suitable sample size for linear regression analysis can be calculated using formula as suggested by Tabachnick and Fidell (2007, p.123) given below:

\section{Sample Size $>50+8 m$}

Where,

$$
\text { " } m \text { " is the number of the independent variables }
$$

In this study, there is just one independent variable. Consequently, a total number of 58 respondents was needed for obtaining reliable results from linear regression analysis, while the sample size representing the 67 cases.

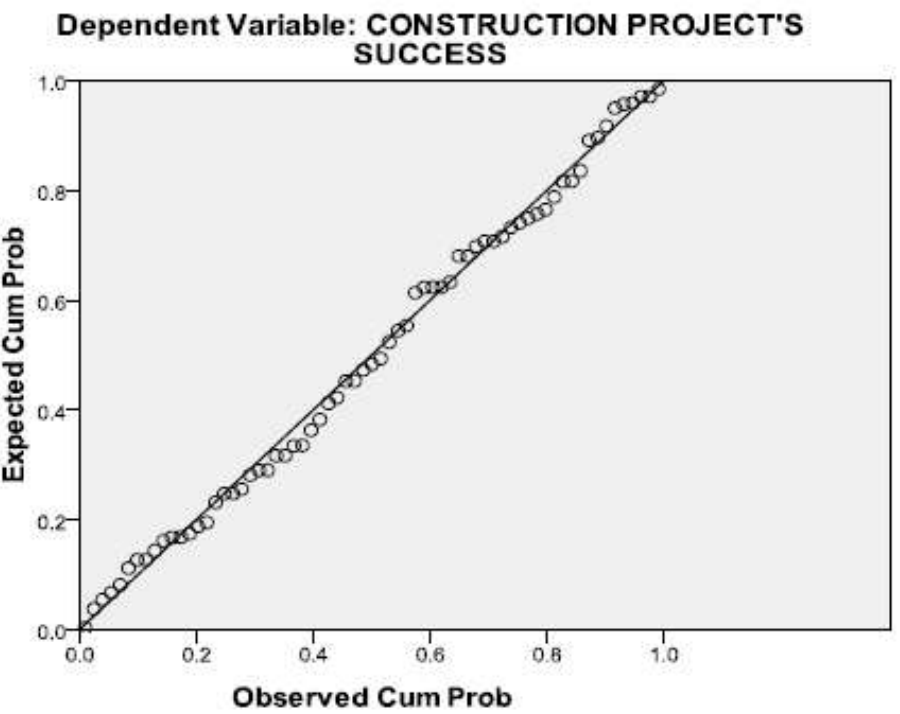

Figure 2: The Normal P-P Plot of Regression Standardized Residual

As mentioned previously, the significant level of alpha in regression analysis is 0.05 within $95 \%$ of confidence level (1-tailed). For example, when the alpha is higher than level of p-value, the hypothesis can be accept, and if the alpha is less than level of p-value, it means that hypothesis is reject. As can be seen in Table 3 and 4, linear regression technique was accomplished in SPSS to investigate the causality Impact of ISO 9001 Certification on the Projects' Success of Large-Scale (AAA) Construction Firms in the 
between dependent variable (ISO 9001), and independent variables (project success, and its criteria). In the regression model 1, Adjusted R square is 0.407 that indicates the independent variable as ISO 9001 accounted for 40.7 percent of the variance in the dependent variable as project success as whole. Likewise, $\beta$ coefficient $(\beta 1=0.645)$ and $T$-test result were significant ( $\mathrm{p}$-value $<0.05)$. Thus, there is strong support for H1.

Also, the results of regression analysis on the main factors of projects' success (hypothesis 2, 3, 4 and 5) were presented in Table 3 and 4, concerning the effects of ISO 9001 certification on construction quality, time length of project, cost of project, and customer's satisfaction respectively. In Model 2, the findings revealed that ISO 9001 certification significantly and positively affected construction quality performance, and it explains $31.8 \%$ of variance in quality. In addition, the beta coefficient $(\beta 2=0.573)$ is shown the positive correlation between ISO 9001 and construction quality by looking at the significance level of T-test ( $\mathrm{p}$-value $<0.05$ ). Hence $\mathrm{H} 2$ is supported.

Table 3: Summary of the Models

\begin{tabular}{|c|c|c|c|c|}
\hline Model & $\mathbf{R}$ & R Square & Adjusted R Square & Std. Error of the Estimate \\
\hline 1 & $0.645^{a}$ & $0 . .416$ & 0.407 & 0.36500 \\
\hline 2 & $0.573^{b}$ & 0.329 & 0.318 & 0.43795 \\
\hline 3 & $0.205^{c}$ & 0.042 & 0.027 & 0.69400 \\
\hline 4 & $0.306^{d}$ & 0.094 & 0.080 & 0.61187 \\
\hline 5 & $0.721^{e}$ & 0.520 & 0.513 & 0.56083 \\
\hline
\end{tabular}

Notes: Predictor: (Constant), ISO 9001; Dependent Variable: Project success ${ }^{a}$ quality $^{b}$, Time ${ }^{c}$, Cost $^{d}$, Customer's satisfaction $^{e} ; \mathbf{p}<\mathbf{0 . 0 5}$

Surprisingly, ISO 9001 certification has statistically insignificant effect on time of project completion. The coefficient of adjusted $R$ square from Table 3, indicating ISO 9001 explained $2.7 \%$ of the variance in time length of projects. Also, standardized coefficient $\beta(\beta 3=0.205)$ and $\mathrm{T}(1.686)$ values were insignificant (p-value of $0.097>0.05$ ). Therefore, $\mathrm{H} 3$ is rejected from regression analysis. Whereas ISO 9001 certification has a significant positive effect on the cost of the projects. In Table 3, the significant adjusted $R$ square value explains $8 \%$ of the variance in cost. In the same way $\beta$ coefficient $(\beta 4=0.306)$ and likewise $T$ value were significant (p-value <0.05) that reflects the positive impact of ISO 9001 on cost of project. Thus, H4 is supported. Lastly, ISO 9001 certification has significant positive influence on customer's satisfaction. The significant values of $\mathrm{T}(8.396)$ and standardized coefficient $\beta(\beta 5=0.721)$ were significant $(p<0.05)$. Moreover, adjusted $R$ square value of Model 5 revealed that ISO 9001 strongly explained $51.3 \%$ of the variance in customer's satisfaction, which confirms strongly $\mathrm{H} 5$.

Table 4: Regression analysis

\begin{tabular}{|c|c|c|c|c|c|}
\hline \multirow[b]{2}{*}{ Model } & \multicolumn{2}{|c|}{ Unstandardized Coefficients } & \multirow{2}{*}{\begin{tabular}{|c|} 
Standardized Coefficients \\
Beta
\end{tabular}} & \multirow{2}{*}{ T-test } & \multirow[b]{2}{*}{ Sig. } \\
\hline & $\mathbf{B}$ & Std. Error & & & \\
\hline 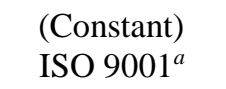 & $\begin{array}{l}1.047 \\
0.634\end{array}$ & $\begin{array}{l}0.345 \\
0.093\end{array}$ & 0.645 & $\begin{array}{l}3.037 \\
6.803\end{array}$ & $\begin{array}{l}0.003 \\
0.000\end{array}$ \\
\hline 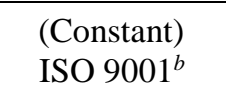 & $\begin{array}{l}0.657 \\
0.631\end{array}$ & $\begin{array}{l}0.414 \\
0.112\end{array}$ & 0.573 & $\begin{array}{l}1.590 \\
5.639\end{array}$ & $\begin{array}{l}0.117 \\
0.000\end{array}$ \\
\hline 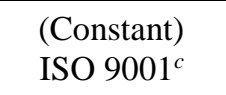 & $\begin{array}{l}2.173 \\
0.299\end{array}$ & $\begin{array}{l}0.655 \\
0.177\end{array}$ & 0.205 & $\begin{array}{l}3.316 \\
1.686\end{array}$ & $\begin{array}{l}0.001 \\
0.097\end{array}$ \\
\hline 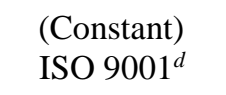 & $\begin{array}{l}2.171 \\
0.405\end{array}$ & $\begin{array}{l}0.578 \\
0.156\end{array}$ & 0.306 & $\begin{array}{l}3.756 \\
2.594\end{array}$ & $\begin{array}{l}0.000 \\
0.012\end{array}$ \\
\hline $\begin{array}{c}\text { (Constant)ISO } \\
9001^{e}\end{array}$ & $\begin{array}{c}-0.813 \\
1.203\end{array}$ & $\begin{array}{l}0.530 \\
0.143\end{array}$ & 0.721 & $\begin{array}{c}-1.534 \\
8.396\end{array}$ & $\begin{array}{l}0.130 \\
0.000\end{array}$ \\
\hline
\end{tabular}


Notes: Predictor: (Constant), ISO 9001; Dependent Variable: Project success ${ }^{a}$ quality $^{b}$, Time $^{c}$, Cost $^{d}$, Customer's satisfaction $^{e} ; \mathbf{p}<\mathbf{0 . 0 5}$

\subsection{Discussion}

This study employed both descriptive and inferential analysis, in order to investigate the impact of ISO 9001 certification on project success, and its main elements within large-scale (AAA) construction firms in Metro Manila, Philippines. The descriptive statistics analysis indicated that 67 managers from the ISO 9001-certified construction projects had high levels of agreement $(M=3.67)$ in implementing the requirements of ISO 9001 standard (QMS). Also, Table 2 demonstrated the impact of ISO 9001 on customer's satisfaction is the highest overall mean score (3.96) in comparison with other criteria of projects' success, this result is consistent with the findings of Mane and Patil (2015) in Indian construction projects. Second most effect of ISO 9001 on the projects' success factors was construction project quality $(\mathrm{M}=3.47)$. Lastly, construction cost $(\mathrm{M}=3.35)$ and time length of project $(\mathrm{M}=3.21)$ were respectively third and forth that obtained the lowest mean scores, these findings are also consistent with the reported study by Ali and Rahmat (2010), who found cost and time occupying lowest ranking by the respondents in ISO 9001-certified construction contractors in Malaysia. Consequently, amongst project success criteria, the only customer's satisfaction was strongly agreed by the respondents as most impact of ISO 9001 certification on project success, whereas the responses of the managers regarding time, cost, and quality were neutral and inconclusive in descriptive analysis.

Therefore, inferential analysis was used to find clearly the impact of the certification of ISO 9001 certificate on construction project success. So, linear regression analysis built five Models, in order to specify the significant contribution of the ISO 9001 certification in predicting project success, and its main factors within large-scale construction companies. As can be seen in Table 4, the direct effects of ISO 9001 certification on construction projects' success as whole was at a 5\% level of significance (H1). Regarding each criterion of project success, regression analysis indicated that the impact of ISO 9001 on construction quality was significant at $0.05(\mathrm{H} 2)$ that provided supporting evidence for the view of Khattak and Arshad (2015, p. 203), who realized the "quality of construction projects is purely depended on the development of such industry and is associated with the implementation of ISO 9001 (QMS) in this industry". Moreover, Model 3 reported that ISO 9001 cannot significantly affect the cost of construction project variable at 0.05 significance level (H3). This finding is also consistent with Ali and Rahmat (2010, p. 33), who justified that ISO 9001 cannot affect time length of construction projects because "the complexity of construction projects can generate excessive variations during construction. It is seldom for the contractors to complete a project on time without changes to the plans or the construction process". While cost of construction project could significantly be influenced at $5 \%$ by ISO 9001 (H4). According to Oakland (2003), the role of ISO 9001 is greatly to ensure that the product or service conforms to customer requirement. Similarly, the outcome of regression analysis revealed a strong contribution of ISO 9001 in satisfying customers that was significant at 5\% level in construction projects (H5).

Furthermore, the degree of influence (effect size) of the predictor variable (ISO 9001) is given by the beta values in regression analysis for each Model. Beta weightings specify the degree and strength of the linear relationship between independent variable and dependent variable/s. According to Cohen et al. (2007, p. $523)$, the effect size can be interpreted in four positions, such as weak $(\beta<0.1)$, modest $(\beta=0.1-0.3)$, moderate $(\beta=0.3-0.5)$, and strong $(\beta>0.5)$. Based on Table 4 , the degree of the impact of ISO 9001 certification with construction projects' success $(\beta=0.645)$, construction quality $(\beta=0.573)$, time $(\beta=0.205)$, cost of project $(\beta=0.306)$, and customer's satisfaction $(\beta=0.721)$ were at strong, strong, modest, moderate, and strong degree respectively. It is proven that the ISO 9001 standard can strongly affect construction projects' success in large-scale companies, and the importance of adopting this standard in construction industry for improving performance, and most significantly for satisfying their clients, in order to achieve project's goals successfully.

\section{Conclusion}

As a quantitative research, this study used the statistical methods to evaluate the effects of ISO 9001:2008 on construction project success, and its criteria within large-scale (AAA) construction firms in Metro Manila, Philippines. Literature review identified that the customer's satisfaction and iron triangle (cost, time, quality) are the main factors of projects' success in view of scholars, these elements are as an effective tool to evaluate the level of projects' success in construction industry. Furthermore, ISO 9001 is a powerful quality technique that can assist projects to achieves their objectives successfully. However, the results of regression analysis of collected data revealed the positive contribution of the ISO 9001 certification with projects' success, customer's satisfaction, and construction quality at strong level. The 
study also observed that the cost of projects can be affected moderately by ISO 9001 certification at a 5\% level of significance. While there was no significant contribution between ISO 9001 and time length of projects. As justified by Ali and Rahmat, 2010), the "complexity" and uncertainty of construction projects (weather, plan changes, etc.) can cause that ISO 9001 cannot be able to help considerably the construction firms in completing their projects on time.

In addition, it is not surprising that the most impact of ISO 9001:2008 is on customer's satisfaction, because the main aim of the framework of this standard is to satisfy customers by establishing an excellent environment to improve quality of the products and services (Mane and Patil, 2015). Interestingly, although construction projects have been implemented ISO 9001:2008 at acceptable level in construction projects, but mean score of construction quality was not quite high in descriptive statistics. So, it can be concluded that the construction firms just adopted ISO 9001 certification to become eligible for tendering in government or huge projects, and also achieving its competitive advantages as a marketing tool. This notion causes that the construction firms focus on "short-term" goals for getting a certificate instead of implementing an effective QMS, and obtaining its benefits in project sites for future (Farooqui and Ahmed, 2009). This study is recommended to the construction companies in emphasizing and focusing more on quality aspects of ISO 9001 certification at project level, instead of achieving just a ISO certificate for quality management system as a marketing tool. Likewise, it is vital to develop a suitable total quality management model at enterprise level, in order to support and assure the success of implementing ISO 9001 standard in construction projects. So, it may cause that ISO 9001 affects more on construction project success, and its criteria.

For this research, there was a limited number of ISO 9001-certified construction projects in Metro Manila, Philippines. Thus, the study was accomplished on a small size that suffered from some limitations in implementing some statistical methods. Lastly, the study is suggested to investigate the effects of ISO 9001:2015 standard that possesses a new framework (Annex SL: 10 clauses) on construction projects' success and its criteria by collecting data from a large sample size for further studies.

\section{Acknowledgement}

The author would like to express his special gratitude to Dr. Joseph B. Juanzon and Mrs. Herminia B. Dimaano for their supports, contributions in completing this article. He also sincerely appreciate to all participating managers, who shared their valuable experiences and opinons regarding the effects of ISO 9001 on the success of their projects from large-scale (AAA) construction companies in Metro Manila, Philippines.

\section{References}

Ali, A.S., \& Rahmat, I. (2010). "The performance measurement of construction projects managed by ISO-certified contractors in Malaysia," Journal of Retail \& Leisure Property, 9(1), pp. 25-35. [Google Scholar]

Cohen, L., Manion, L., \& Morrison, K. (2007). Research Methods in Education (6th ed.), Abingdon, Oxon: Routledge from Taylor \& Francis Group. [Google Scholar]

Farooqui, R.U., \& Ahmed, S.M. (2009). "ISO 9000: A Stepping Stone to Total Quality Management for Construction Companies?," In Proceedings of the Seventh Latin American and Caribbean Conference for Engineering and Technology, pp.1-9. Retrieved from http://laccei.org/LACCEI2009Venezuela/p249.pdf. [Accessed in March 24, 2016]. [Google Scholar]

Golob, K., Bastič, M. and Pšunder, I. (2013). "Influence of Project and Marketing Management on Delays, Penalties, and Project Quality in Slovene Organizations in the Construction Industry,” Journal of Management in Engineering, 29(4), pp. 495-502. [Google Scholar]

Hair, J.F., Black, W.C., Babin, B.J., Anderson, R.E., and Tatham, R.L. (2006). Multivariate data analysis (6th ed.), Pearson Prentice Hall. New Jersey. [Google Scholar]

Hajiagha, H. Akrami, H. Hashemi, S., \& Mahdiraji, H. (2015). “An Integer Grey Goal Programming For Project Time, Cost and Quality Trade-Off,” Inzinerine Ekonomika-Engineering Economics, 26(1), pp. 93-100. [Google Scholar]

Hoonakker, P., Carayon, P., \& Loushine, T. (2010). "Barriers and benefits of quality management in the construction industry: An empirical study," Journal of Total Quality Management \& Business Excellence, 21(9), pp. 953-969. [Google Scholar]

ISO (2008). "ISO 9001:2008 Quality management systems - Requirements," International Organization for Standardization, Geneva, Switzerland. Retrieved from http://www.dac.com.cn/upload/fckupload/file/140783376441 41957785915.pdf. [Accessed in June 18, 2016]. [Google Scholar] 
ISO (2010). "ISO 9001 for Small Business: What to do," International Organization for Standardization, Switzerland.

Retrieved

from http://www.inlac.org.co/web/images/stories/normas/NORMAS2010/sme\%25209001

$\% 252$ 02008.pdf. [Accessed in June 18, 2016]. [Google Scholar]

ISO (2014). "The ISO Survey of Management System Standard Certifications - 2014," International Organization for Standardization, Geneva, Switzerland. Retrieved from http://www.iso.org/iso/isosurvey_2014.zip. [Accessed in June 18, 2016]. [Google Scholar]

Kerzner, H. (2009). Project Management: A Systems Approach to Planning, Scheduling, and Controlling (10th ed.), New Jersey: John Wiley \& Sons, Inc. [Google Scholar]

Khattak, A.B., \& Arshad D.I. (2015). "Barricades in Implementation and Adoptation Level of ISO-9001 in Construction Industry of Pakistan," European Journal of Business and Management, 7(13), pp. 203211. [Google Scholar]

Lee, D.E., Lim, T.K., \& Arditi, D. (2011). “An Expert System for Auditing Quality Management Systems in Construction," Computer-Aided Civil and Infrastructure Engineering Journal, 26, pp. 612-631. [Google Scholar]

Mane, P.P., \& Patil, J.R. (2015). "Quality Management System at Construction Project: A Questionnaire Survey," Int. Journal of Engineering Research and Applications, 5(3), pp.126-130. [Google Scholar]

Oakland, J. S. (2003). Total Quality Management: text with cases (3rd ed.). Jordan Hill, Oxford, UK. [Google Scholar]

PCAB (2015). "PCAB List of Special Licenses Issued for Calender Year CFY 2015-2016,” Sep. 4, 2015. Retrieved from https://ciap.dti.gov.ph/sites/default/files/publications/PCAB\%20List\%20of\%20Licensed\%20Contract ors\%20for\%20 CFY\%202015-2016\%20as\%20of\%2004\%20September\%202015.pdf. [Accessed in March 24, 2016]. [Google Scholar]

Polat, G., Damci, A., \& Tatar Y. (2011). "Barriers and Benefits of Total Quality Management in the Construction Industry: Evidence from Turkish Contractors," In Proceedings of Seventh Research/Expert Conference with International Participations "QUALITY 2011”, pp. 1115-1120. Retrieved from http://www.quality.unze.ba/zbornici/QUALITY\%202011/185-Q11140.pdf/Dec,2012.[Accessed in March 24, 2016]. [Google Scholar]

Proust, E. (2011). How to achieve success in iconic construction projects: the iron triangle hegemony Chalmers University of Technology (A Master's Thesis), Chalmers, Göteborg, Sweden. Retrieved from http://publications.lib.chalmers.se/records/fulltext/155090.pdf.[Accessed in March 14, 2016]. [Google Scholar]

Saunders, M., Lewis, P. and Thornhill, A. (2009) Research Methods for Business Students (5th ed.), Edinburgh Gate, Harlow: Pearson. [Google Scholar]

Shafiq, M., Mirza, K., Abid, K., \& Naeem, M.A. (2014). "Effect of ISO 9000 Certification on TQM Implementation," Journal of Quality and Technology Management, 5(2), pp. 01-26. [Google Scholar]

Shahu R., Pundir, A. K., \& Ganapathy, L. (2012). "An Empirical Study on Flexibility: A Critical Success Factor of Construction Projects,” Global Journal of Flexible Systems Management," 13(3), pp. 123128. [Google Scholar]

Tabachnick, B.G. and Fidell, L.S. (2007). Using multivariate statistics (5th ed.), Boston: Pearson Education. [Google Scholar]

\section{Biography of Author}

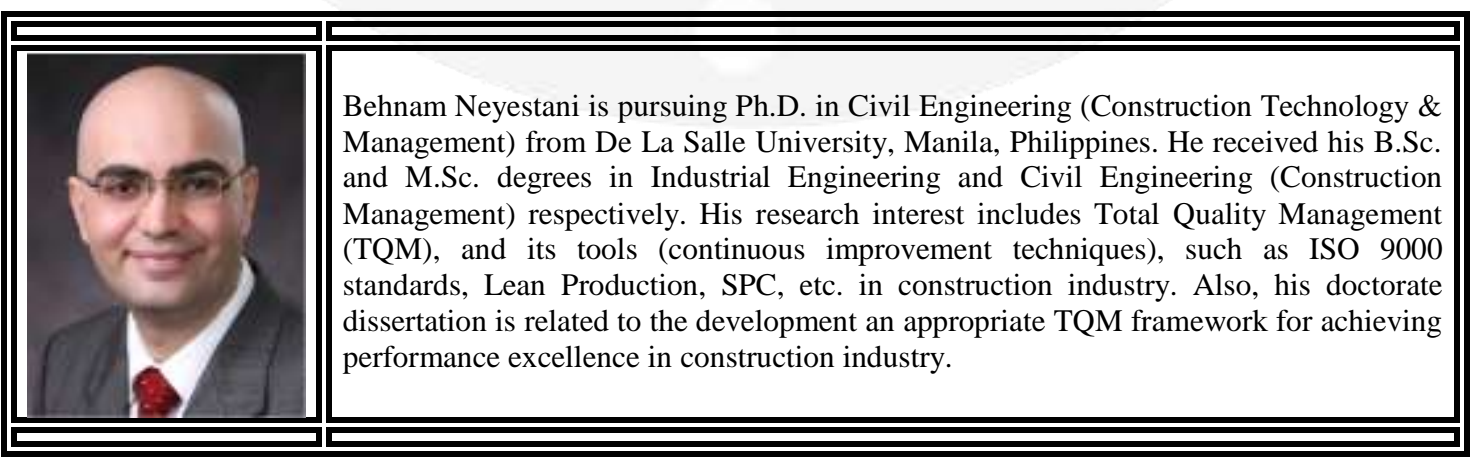

